\title{
Discussion on the Effective Training Programs of Comprehensive Abilities of Students in Art Design Majors of Higher Vocational Colleges to Meet the Needs of Social Development
}

\author{
Yu Song, Yumin Huang \\ Jiangxi Vocational College of Industry \& Engineering, Pingxiang, Jiangxi, China
}

Keywords: Art Design majors in higher vocational colleges; Comprehensive abilities; Effective training; Programs.

\begin{abstract}
Higher vocational education is an important part of China 's education. Effective development of vocational education can improve the quality of higher vocational education. For the teaching of Art Design majors in higher vocational colleges, in order to make students to meet the needs of social development, the cultivation of their comprehensive abilities needs to be focused, including: social ability, professional and technical ability, and ability of sustainable development.
\end{abstract}

\section{Introduction}

With the rapid development of the social economy, the country has to improve its international competitiveness, and the demand for talents is higher. Talent is the cornerstone of a country's development. For students in Art majors, they not only need to be familiar with design software, and be good at graphic drawing, but also should have strong ability of design (aesthetic creativity). Only in this way can they better adapt to the needs of social development. Therefore, higher vocational colleges should pay attention to the effective training of students' comprehensive vocational ability. It mainly includes: Good understanding to the related tasks, work content and products of art and design; Keen understanding and observation to the audiences of the design and market expectations; In terms of design concept, they should have a certain aesthetic feeling, style and modernity, and be keen to the shapes and colors of the design works.

\section{The Present Situation of Teaching of Art Design Majors}

At present, the teaching of Art Design majors in higher vocational colleges mainly has the following problems: (1) The students of the major generally have a poor cultural foundation. (2) At present, there is a phenomenon. In the second year of high school, some students have chosen to become art students because of their poor cultural foundation. These students have no artistic foundation and only spend two years studying art, which makes the students of Art Design majors in higher vocational colleges not only have a poor cultural foundation, but also have a poor artistic foundation. (3) In society, people have misunderstood the major of Art Design. The relevant admission policy has further deepened society's misunderstanding. Even some students and parents think higher vocational colleges are relatively worse compared to ordinary junior colleges. (4) Some students and parents lack the knowledge of education in higher vocational colleges, especially the training goals and employment prospects of higher vocational colleges, which puts them in a wait-and-see mode for higher vocational colleges. At the same time, some students think that Art Design majors in higher vocational college can't learn useful and high-end knowledge. they worry that they can't find better jobs in the future. (5) Some students in Art Design majors have problems with unclear goals, poor learning attitude and insufficient learning motivation. (6) The collective spirit and the sense of organization discipline of them are bad. At the same time, compared with other 
majors, students in this major often absence from class. (7) Since Art Design majors are mostly practical courses, higher vocational colleges didn't do well in the practice teaching of this major. [1]

\section{The Effective Training Programs of the Comprehensive Abilities of Students in Art Design Majors of Higher Vocational Colleges}

Transforming Education and Teaching Concept. In order to improve the teaching quality of Art Design majors, higher vocational colleges must transform education and teaching concept. The colleges need to set up advanced art design teaching ideas. The relevant people in charge of the majors and teachers should learn the documents issued by the National education departments, and learn the reform experience and teaching methods from other higher vocational colleges that are good in Art and Design majors, so that they can formulate scientific and rational art design teaching plans by combining with their own actual situation. At the same time, higher vocational colleges should pay more attention to the innovation ability and comprehensive abilities of students majoring in Art Design in order to promote the development of their design ability. The colleges should change from professional education to education for all-around development. The teaching practice of Art Design majors is transformed from the teaching of knowledge to the development of thinking. Teachers now focus on the cultivation of students' creative and practical ability. In the teaching activities of Art Design Majors, teachers should strengthen communication with students to build a harmonious relationship and create a good learning environment for them. Teachers should encourage students to have different ideas and focus on improving the students' thinking ability. What's more, teachers should distinguish the teaching contents from that of ordinary universities, and make better settings for cultural courses, so as to reach the requirements of optimization and simplification. Teachers should highlight the professional training and key courses in class teaching, so as to cultivate the comprehensive abilities of students in Art Design Majors, which will make them better adapt to the requirements of the society.[2]

In addition, in the teaching of Art Design Majors, teachers should innovate the teaching modes. Making the following points: (1) The comprehensive professional abilities of students majoring in Art Design should be set as the top priority, which combines the requirements of the majors and the development needs of the industry. The colleges set up a "graphic design studio". Teachers lead students to do practice activities combining teaching, learning, and doing. By combining the theory with practice, the practice activities are held in the enterprises, which will further improve the students' comprehensive abilities such as learning ability, professional skills, cooperation ability. (2) During teaching, teachers should develop a variety of teaching methods based on the cultivation of students' creative learning ability to improve the students' adaptability. At the same time, teachers should guide students to appreciate, analysis, and then create a series of graphic designs. While the students can be familiar with and use the corresponding skills, give them the specific project so as to further improve their professional skills. (3) The "graphic design studio" can effectively solve the problems of practice places and practice facilities, so that the students can keep in contact with the society. Their designs can be close to life. It can also effectively ease the students' employment psychological pressure.

Optimizing the Major Setup and Training Programs. During the teaching of art design in higher vocational colleges, if teachers only cultivate students' ability of design drawings, they will ignore the cultivation of student's practical ability, which leads to idle theorizing. Thus, they are unable to cultivate the talents can adapt to social development needs. Therefore, higher vocational colleges need to optimize the major setup and training programs in the premise of market environment, and pay attention to the cultivation of students' practical ability. The main content is: Practical ability; Ability to solve problems in occupation posts, and ability to convert design drawings into entities. The construction of the practice teaching system. To highlight the teaching characteristics of Art Design Majors in higher vocational colleges, and focus on the goal and quality of talent training. For the setting of curriculum, vocational colleges should control the proportion of practical courses of Art Design Majors in a reasonable way. Generally, the practice courses should be more than three. For the arrangement of the teaching content, related people in charge should 
combine with the needs of social development, reasonably arrange teaching content in order to strengthen the practice ability of students in Art Design Majors. [3]

Focusing on Cultivating Students' Creative Thinking. Creative thinking refers to a way of thinking that actively seeks solutions to problems, which has great influence on art design. As an important part of China's higher education, higher vocational colleges undertake the task of cultivating high-level innovative talents. This leads to the result that in the aspect of major setup, most higher vocational colleges only pay attention to the teaching of professional technical ability, and ignore the teaching of other kinds of courses, which causes the lacking of innovative consciousness.[4] Therefore, in the teaching of art design in higher vocational colleges, we should pay more attention to cultivating students' innovation ability and expanding their knowledge, so that their comprehensive quality will be improved. Here are the requirements:

Cultivating students' ability to observe life and nature. Observation is a kind of perceptual activity which has certain permanence, plans and purpose. It also refers to the perceptual process of people's perception of reality. In art design teaching, teachers should guide students not to solve the problems in the learning process with traditional routines and habitual ways of thinking, but to solve them creatively. Art Design Majors are closely related to people's life. Many ideas in art design activities come from people's daily life. Teachers can ask students to observe around people's life style, behaviors, customs, etc. Through this way, the student can gain creative thinking inspiration from their daily life.

Cultivating students' wide interests and rich knowledge. If a design is not creative, it must be a failure. To be a good designer, he should fully understand and master professional knowledge and skills, he still needs to have rich knowledge, understand and even be proficient in the knowledge of other subjects. Moreover, creative imagination also requires rich knowledge of designers. In order to acquire the corresponding knowledge, the designer should learn and understand all kinds of knowledge. Therefore, in the professional teaching of art design, teachers should pay attention to the training of students' wide interests and hobbies, and further enrich their knowledge, so as to improve their innovative thinking greatly.

Cultivating students' comprehensive quality and cultural deposits. The designers' culture deposits directly determines the quality of the design works. Therefore, in the teaching of art design, teachers should teach students the traditional Chinese art culture and guide them to learn the folk art. Teachers need to cultivate students' culture deposits, and pay attention to guide students to dig new luminescent spots in the traditional culture, explore the new way of thinking. They should also encourage students to break through their limitations, do innovative designs with creative thinking, so as to inherit and develop the traditional culture creatively.

Higher vocational colleges can improve the design ability of students majoring in Art Design by cultivating excellent talents with innovative spirit. The requirements are: Optional courses in social sciences, art, literature and so on should be offered to make their knowledge structure more reasonable; Establishing the corresponding clubs to make their mind get inspired and enrich their experience; The poster design of the school's activities can be designed by students majoring in Art Design. At the end of each term, the design exhibition will be held for the students of this major. The most creative works will be selected by the teachers and students of the whole college. Teachers can also lead students to the art design competition.(e.g. the National College Students' Advertising Art Competition). Through these methods, students' innovative thinking can be effectively trained. Their thinking width and aesthetic ability can be further improved. Therefore, they can better adapt to the needs of social development. [5]

Improving the Teaching Conditions and the Overall Quality of the Teaching Staff. In order to effectively cultivate students' comprehensive abilities, vocational colleges should establish an after-school training base for students of Art Design Majors to carry out practical activities. The designers of enterprises, the masters working in production lines and the technologist are major trainers. These people can guide students to design works, to carry out the actual operation in the production lines, and make students be able to directly face the customers, fully understand the demand of the market, and be fully familiar with the whole design process. At the same time, by 
involving in the specific projects, being in close contact with relevant drawing materials, machinery and equipment, and communicating with the people in charge of the enterprise, the workers, the students can effectively improve their professional skills, interpersonal skills, hands-on ability, cooperation ability, etc. In addition, teachers in higher vocational colleges should possess strong professional skills and rich practical experience. They should also have relevant certificates (such as: certificates of graphic designers, 3D animation design engineer certificates, etc.). In this way can the overall quality of the teaching team be improved continually. The students' comprehensive abilities which meet the needs of social development can also be better trained.[6]

Strengthening Students' Career Planning and Learning. Through the study of career planning, students of Art Design Majors can better understand their own personalities, abilities and their work. Their individual career consciousness can also be cultivated. Their understanding toward themselves and the career can be improved in order to make them get ready for the industry and career orientation. Career planning can help students accurately locate their own values, effectively avoid the phenomenon of blind employment in the process of choosing a job, so as to set up a correct career view. It can also help students make reasonable arrangements for their study time, which can improve their learning efficiency. Therefore, in the professional teaching of Art Design, teachers should regularly ask students to write a career plan. The content includes: The strengths, weaknesses, interests, yearning careers, the current study situation. They are asked to introspect the defects of their learning, which allows students to recognize themselves and their direction in the future, so as to further improve their comprehensive abilities.

\section{Conclusion}

All in all, although the main job of schools is teaching, the basic task is to cultivate students to make them have the comprehensive abilities to adapt to social development needs. In the teaching of art design in higher vocational schools, the teachers effectively train the students' comprehensive abilities to meet the needs of social development, and help them finding a better job through changing and creating teaching modes, setting up reasonable curriculum content, formulating scientific and reasonable teaching plans, strengthening the cultivation of student's creative thinking and the learning of career planning.

\section{References}

[1] Chun-Hong Xu. How to Cultivate the Design Ability of Art Design Students in Higher Vocational Colleges [J]. Journal of Hubei Correspondence University, 2015(02):105-106.

[2] Ya-Li Wang. Analysis on the Project - oriented Teaching Mode of Art Design Majors in Higher Vocational Colleges [J]. Art Education Research, 2017(07):146-148.

[3] Jin-Song Zhang. On the Cultivation of Students' Creative Thinking in Art Design Teaching in Higher Vocational Colleges [J]. The Modern Occupation Education, 2016(19):134-135.

[4] Zhen-Yu Wu. Research on the Reform and Innovation of Project Teaching in Art Design Majors in Higher Vocational Colleges [J]. Science \& Technology Information, 2016(29):124-126.

[5]En-Cui Li. Cultivation of Applied Talents in Art Design Majors in Higher Vocational Education [J]. Knowledge Economy, 2015(05):137.

[6]Ying Chen. Reflections on the Teaching Reform of Art Design in Higher Vocational Education [J]. Kaoshi Zhoukan, 2017(69):167. 